Check for updates

Cite this: RSC Adv., 2018, 8, 8228

Received 13th December 2017 Accepted 2nd February 2018

DOI: 10.1039/c7ra13303k

rsc.li/rsc-advances

\section{Graphene-supported platinum/nickel phosphide electrocatalyst with improved activity and stability for methanol oxidation $\dagger$}

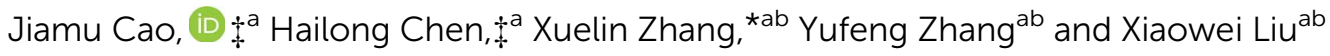 \\ In this paper, we report a novel catalyst using $\mathrm{Ni}_{2} \mathrm{P}$ as a cocatalyst of $\mathrm{Pt}$ supported on graphene for methanol \\ oxidation. The results reveal that the electrocatalytic activity and stability of the as-prepared catalyst for \\ methanol oxidation are significantly enhanced by the addition of $\mathrm{Ni}_{2} \mathrm{P}$. The reason for the increased \\ activity and stability is ascribed to complex electron transfer between $\mathrm{Pt}, \mathrm{Ni}_{2} \mathrm{P}$, and graphene, which \\ gives rise to the eventual promotion of $\mathrm{CO}_{\text {ads }}$ electrooxidation reaction kinetics. The present study \\ implies that the as-prepared $\mathrm{Pt}-\mathrm{Ni}_{2} \mathrm{P} /$ graphene will be a promising candidate as an anode electrocatalyst \\ in direct methanol fuel cells.
}

\section{Introduction}

The direct methanol fuel cell (DMFC) as a promising power source for portable electronic devices has attracted more and more attention due to its simple system design, high energy density, and low pollutant emission. ${ }^{1-3}$ These advantages are enough to make it a promising way to address the existing environmental emission issues from fossil energy. ${ }^{4}$ However, reducing cost is an urgent problem to solve in many research fields, ${ }^{5,6}$ therefore, reducing the dosage of precious metal catalyst, or improving its catalytic efficiency is an important means to push forward the commercialization of DMFCs. ${ }^{7}$

The main reason for DMFC anode rate limitation is apparently the sluggish electrooxidation of adsorbed carbon monoxide, an intermediate product of anodic methanol oxidation. ${ }^{8}$ Efforts to mitigate CO poisoning of Pt nanoparticles can be made through the addition of some metals, such as $\mathrm{Ru},{ }^{9-11}$ $\mathrm{Sn},{ }^{12} \mathrm{Ni}^{13}$ Among them, nickel-based nano-materials not only have been proved to show electrocatalytic activity toward alcohols oxidation but also have been used in the hydrogen evolution reaction, ${ }^{14,15}$ the hydrolytic dehydrogenation, ${ }^{16}$ the electrolytic hydrogen generation, and the hydrogen peroxide reduction reaction, ${ }^{17,18}$ as non-noble metal catalysts.

$\mathrm{N}$-Doped carbon-encapsulated $\mathrm{Ni}$ nanoparticles give an effective electrocatalytic activity and long-term stability for ethanol oxidation in the alkaline aqueous electrolyte. ${ }^{19,20}$

${ }^{a}$ Key Laboratory of Micro-Systems and Micro-structures Manufacturing, Ministry of Education, Harbin 150001, China. E-mail: zhangxuelin@hit.edu.cn

${ }^{b}$ MEMS Center, Harbin Institute of Technology, Harbin 150001, China

$\dagger$ Electronic supplementary information (ESI) available. See DOI: $10.1039 / \mathrm{c} 7 \mathrm{ra} 13303 \mathrm{k}$

\$ These authors contributed equally to this work.
$\mathrm{NiOOH}$ and $\mathrm{NiO}$ present the superior methanol electrocatalytic oxidation performance. ${ }^{21,22}$ Besides these, $\mathrm{Ni}_{2} \mathrm{P}$ was found to be able to enhance the activity and stability of carbon blacksupported palladium and platinum nanoparticles toward alcohols, ${ }^{23-25}$ which revealed that the incorporation of $\mathrm{Ni}_{2} \mathrm{P}$ gives rise to promote the electrooxidation of methanol and resistance to CO poisoning.

On the other hand, the carrier plays an important role in the catalytic performance. ${ }^{26,27}$ Graphene, mother of all graphitic forms, is considered as the most promising supporting material for carbon black and carbon nanotube. ${ }^{28-30}$ Many metallic compounds which combined with graphene have been reported to form complex hybrid structure and display superior catalytic performance compared to naked particles. ${ }^{31,32}$ Graphene sheets in the above structure act as not only a buffer zone of volume change of the active materials but also a good electron transfer medium. ${ }^{33}$

Inspired by these previous findings, we attempt to using graphene as a carrier to examine the possible promotion of $\mathrm{Pt}$ by $\mathrm{Ni}_{2} \mathrm{P}$ in methanol oxidation for DMFC. To date, we have not found reported findings combining $\mathrm{Pt}, \mathrm{Ni}_{2} \mathrm{P}$, and graphene to synthesize high qualified catalyst for methanol oxidation. Herein, we first prepared $\mathrm{Pt}-\mathrm{Ni}_{2} \mathrm{P} /$ graphene catalyst for DMFC by a microwave assisted ethylene glycol method. The physical structure and electrochemical performance of the as-prepared catalysts were characterized and analyzed. A possible mechanism of the interaction between $\mathrm{Pt}, \mathrm{Ni}_{2} \mathrm{P}$, and graphene was also discussed.

\section{Experimental}

\subsection{Synthesis process}

The $\mathrm{Pt}-\mathrm{Ni}_{2} \mathrm{P} /$ graphene catalyst synthesis process as schematically displayed in Fig. $1 \mathrm{a}$. $\mathrm{Ni}_{2} \mathrm{P}$ nanoparticles supported on 


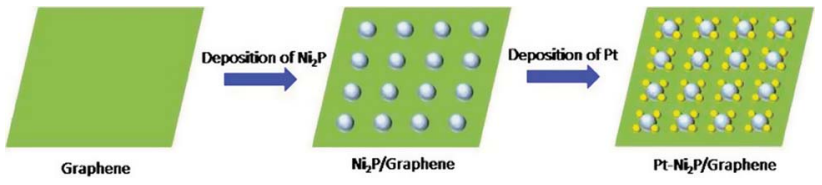

Fig. 1 Schematic diagram of synthesizing Pt-Ni2P/graphene catalyst

graphene $\left(\mathrm{Ni}_{2} \mathrm{P} / \mathrm{G}\right)$ were first prepared by a typical thermal reaction. ${ }^{25}$ The $5 \mathrm{mg}$ GO and $0.3 \mathrm{~g} \mathrm{NiS}_{2}$ were mixed in $20 \mathrm{~mL}$ distilled water and subjected to ultrasonic vibration to form a homogeneous suspension. Then $1.03 \mathrm{~g} \mathrm{NaH} \mathrm{NO}_{2} \cdot \mathrm{H}_{2} \mathrm{O}$ was dispersed in $20 \mathrm{~mL}$ distilled water and mixed with the above suspension. Then the mixture was calcined at $500{ }^{\circ} \mathrm{C}$ for $1 \mathrm{~h}$ and cooled to room temperature. The solid obtained was washed thoroughly with distilled water and absolute ethyl alcohol to remove the by-products. After that, the wet products were dried at $80^{\circ} \mathrm{C}$ for $12 \mathrm{~h}$ in a vacuum oven.

Then the obtained product dispersed into ethylene glycol (EG) and isopropyl alcohol in a breaker under stirring for $1 \mathrm{~h}$ and ultrasonic treatment for $3 \mathrm{~h}$ to form a uniform ink. Then $\mathrm{H}_{2} \mathrm{PtCl}_{6}-\mathrm{EG}$ solution was added and stirred for $2 \mathrm{~h}$. The $\mathrm{pH}$ value of the ink was adjusted by $\mathrm{NaOH}-\mathrm{EG}$ solution drop by drop until its value reached 12 . The next step was to place the breaker the center of a microwave oven for consecutive heating time for $65 \mathrm{~s}$. The solution was cooled down to room temperature and then dilute $\mathrm{HNO}_{3}$ solution was added to the mixture to adjust $\mathrm{pH}$ value to 4 . The mixture was kept stirring for $12 \mathrm{~h}$ and then the product was washed repeatedly with ultrapure water until no $\mathrm{Cl}^{-}$was detected. The homemade $\mathrm{Pt}-\mathrm{Ni}_{2} \mathrm{P} /$ graphene catalyst was dried for $3 \mathrm{~h}$ at $80{ }^{\circ} \mathrm{C}$ in a vacuum oven and then stored in a vacuum vessel. Theoretically, the $\mathrm{Pt}$ and $\mathrm{Ni}_{2} \mathrm{P}$ loading of the $\mathrm{Pt} / \mathrm{Ni}_{2} \mathrm{P}-$ graphene was $20 \mathrm{wt} \%$ and $5 \mathrm{wt} \%$, respectively. For the purpose of comparison, the Pt/graphene catalyst was prepared without the addition of $\mathrm{Ni}_{2} \mathrm{P}$ using the similar procedure mentioned above.

\subsection{Preparation of the working electrode}

The catalyst slurry was prepared by ultrasonically dispersing $4 \mathrm{mg}$ catalyst in the solution of $0.2 \mathrm{~mL}$ ethanol, $0.8 \mathrm{~mL}$ ultrapure water and $20 \mu \mathrm{L}$ Nafion (5 wt\% solution in a mixture of lower aliphatic alcohols and DuPont water) for $30 \mathrm{~min}$. A glassy carbon electrode (GCE) with the diameter of $4 \mathrm{~mm}$ was polished with alumina suspensions and served as the underlying substrate of the working electrode. A quantity of $5 \mu \mathrm{L}$ of the dispersion was extracted out on the top of the GC followed by drying at room temperature for $4 \mathrm{~h}$.

\subsection{Electrochemical measurements}

Electrochemical characterizations of the catalysts were carried out in a standard three-electrode cell using a Pt wire counter electrode and a $\mathrm{Hg} / \mathrm{Hg}_{2} \mathrm{SO}_{4}$ reference electrode at room temperature ( $c a .298 \mathrm{~K}$ ). In the following, all potentials were given relative to a reversible hydrogen electrode (RHE). Cyclic voltammetry (CV) was conducted at a scan rate of $50 \mathrm{mV} \mathrm{s}^{-1}$ with the potential range from $0 \mathrm{~V}$ to $1.2 \mathrm{~V}$. To compare the long- term performance of the catalysts for methanol oxidation, chronoamperometry (CA) tests were used in a solution of $0.5 \mathrm{M}$ $\mathrm{H}_{2} \mathrm{SO}_{4}$ and $0.5 \mathrm{M} \mathrm{CH}_{3} \mathrm{OH}$ for $3000 \mathrm{~s}$ with the step potential of $0.6 \mathrm{~V}$. All the electrochemical tests were carried out with CHI650D electrochemical working station.

\section{Results and discussion}

The elemental and phase compositions of the catalysts were characterized by energy dispersive X-ray spectroscopy (EDS) and X-ray diffraction (XRD). As shown in Fig. 2a, elements of Ni, P and $\mathrm{Pt}$ are observed in EDS spectra of $\mathrm{Pt}-\mathrm{Ni}_{2} \mathrm{P} /$ graphene. Elemental mapping images in Fig. $2 \mathrm{~b}$ shows that $\mathrm{Ni}, \mathrm{P}$, and $\mathrm{Pt}$ homogeneously distribute on the transparent graphene nanosheet. The formation of $\mathrm{Ni}_{2} \mathrm{P}$ phase in the as-prepared catalyst was confirmed by the XRD patterns, as shown in Fig. 2c, where the observed diffraction peaks of $\mathrm{Ni}_{2} \mathrm{P}$ can be indexed to a hexagonal phase. Besides this, the diffraction peaks of Pt (1 1 1), Pt (2 20 ), and Pt (3 11 ) are also observed, indicating Pt forms the face-centered cubic (fcc) crystal structure. These results suggest that nanoparticles of $\mathrm{Pt}$ and $\mathrm{Ni}_{2} \mathrm{P}$ have been successfully synthesized and supported on graphene. Moreover, it should be noteworthy that the $\mathrm{C}(002)$ peak near $25^{\circ}$ appears in the pattern of $\mathrm{Pt} / \mathrm{graphene}$ but is absent in the pattern of $\mathrm{Pt}-\mathrm{Ni}_{2} \mathrm{P} /$ graphene. This big difference reveals that $\mathrm{Ni}_{2} \mathrm{P}$ nanoparticles could reduce the stacking of graphene sheets, acting as a kind of spacer to

a)

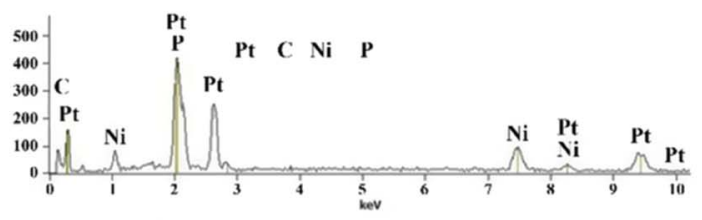

b)
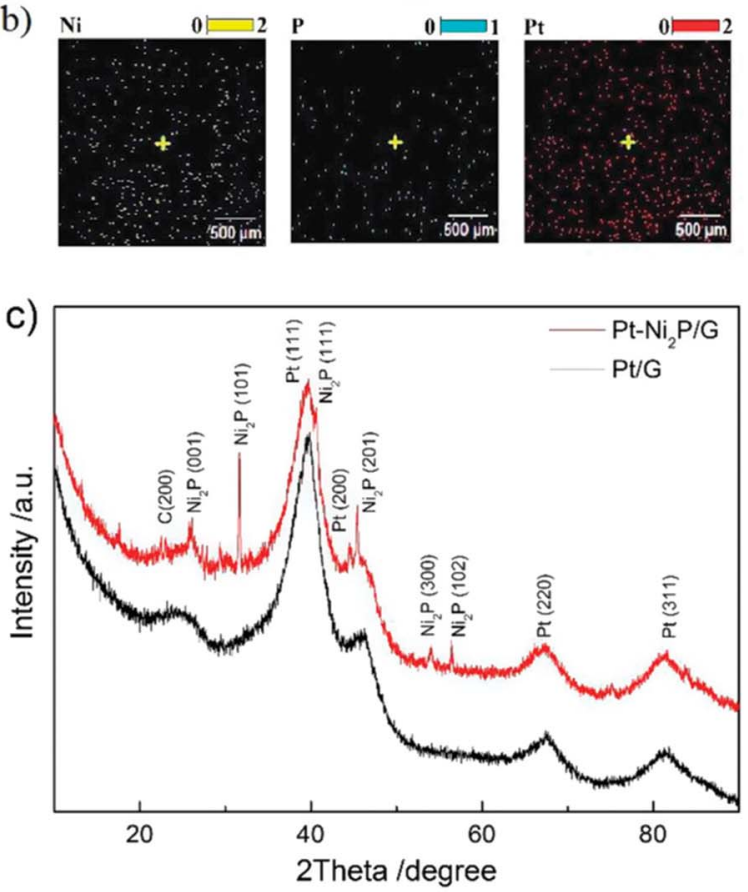

Fig. 2 EDS spectra (a) and elemental mapping images (b) of $\mathrm{Pt}-\mathrm{Ni}_{2} \mathrm{P}$ / graphene; XRD pattern (c) of $\mathrm{Pt}-\mathrm{Ni}_{2} \mathrm{P} /$ graphene and $\mathrm{Pt} /$ graphene. 
help graphene maintain its large surface area and high mass transfer efficiency.

The structure and morphology of the prepared catalysts were characterized by TEM, and the results are shown in Fig. 3a and Fig. 3b. It can be seen that platinum particles are well dispersed on graphene support. The diameters of the Pt particles on the two catalysts range from 2 to $4 \mathrm{~nm}$ (Fig. 3d), and the incorporation of $\mathrm{Ni}_{2} \mathrm{P}$ does not lead to an obvious change in the sizes of Pt particles. On the HRTEM image (Fig. 3c) describing the crystalline nature of $\mathrm{Pt}-\mathrm{Ni}_{2} \mathrm{P}, \mathrm{Ni}_{2} \mathrm{P}$ nanoparticles can be observed with a finger lattice of $0.502 \mathrm{~nm}$, corresponding to the (111) facet. It also shows the reduced Pt particles have successfully adhered to $\mathrm{Ni}_{2} \mathrm{P}$ particles deposited on graphene sheets. In this contact, electron transfer might occur and changes the crystal lattice of atoms, which decrease van der Waals forces between separated graphene sheets, well accounting for the reduced aggregation and disappeared $\mathrm{C}$ (002) peak.

To confirm the existence of electron interaction, X-ray photoelectron spectroscopy (XPS) was carried out, and the results are shown in Fig. 4. It can be seen that the Pt $4 \mathrm{f}$ peaks of the $\mathrm{Pt} / \mathrm{G}$ catalyst at binding energies of $69.88\left(\mathrm{Pt}_{4 \mathrm{f}_{7 / 2}}\right)$ and 72.98 (Pt $4 \mathrm{f}_{5 / 2}$ ) eV move to lower binding energies of 69.08 and $72.28 \mathrm{eV}$ in $\mathrm{Pt}-\mathrm{Ni}_{2} \mathrm{P} / \mathrm{G}$ catalyst, respectively. This shift is likely to an indicator of a partial electron transfer from $\mathrm{Ni}_{2} \mathrm{P}$ to $\mathrm{Pt}$, which might change the electronic structure and density of state of Pt atoms and thus weaken the binding energy of strongly adsorbed and poisonous intermediates, ${ }^{34}$ laying a theoretical foundation for the enhanced catalytic activity and stability in following electrochemical tests.

In electrochemical tests, the cyclic voltammogram (CV) curves of $\mathrm{Pt}-\mathrm{Ni}_{2} \mathrm{P} /$ graphene and $\mathrm{Pt} /$ graphene were characterized in $\mathrm{N}_{2}$ saturated $0.5 \mathrm{M} \mathrm{H}_{2} \mathrm{SO}_{4}$ solution, and the results are
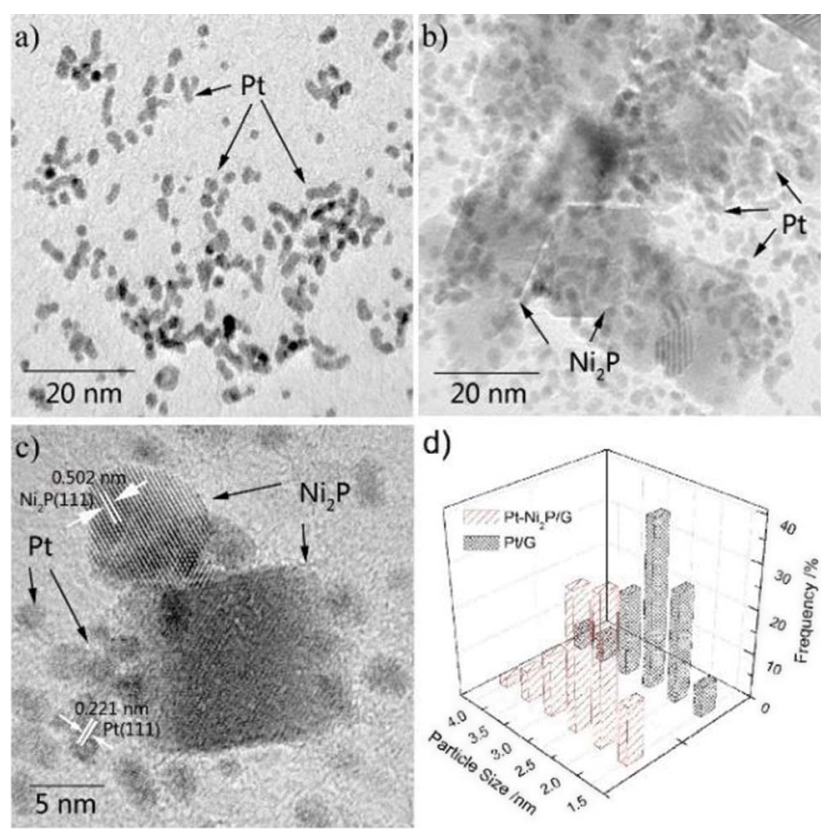

Fig. 3 TEM images of Pt/graphene (a) and $\mathrm{Pt}-\mathrm{Ni}_{2} \mathrm{P} /$ graphene (b); HRTEM image of $\mathrm{Pt}-\mathrm{Ni}_{2} \mathrm{P} / \mathrm{graphene}$ (c); particle size distribution (d) of $\mathrm{Pt}-\mathrm{Ni}_{2} \mathrm{P} /$ graphene and $\mathrm{Pt} /$ graphene.

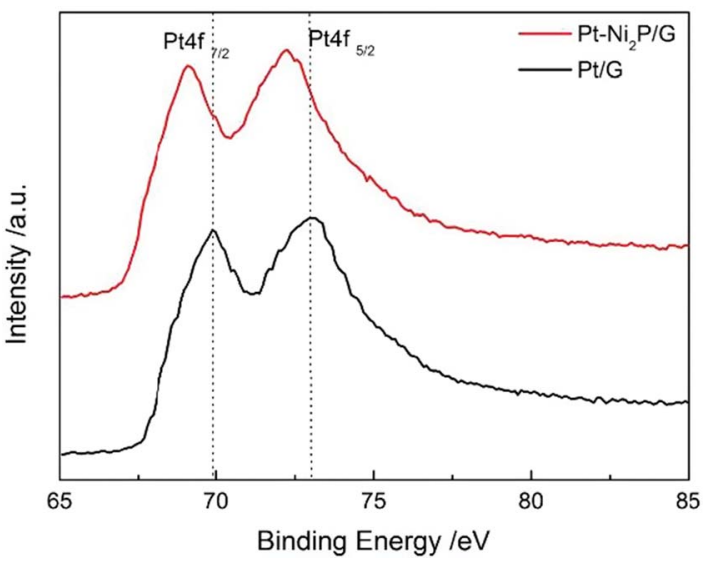

Fig. 4 XPS spectra of $\mathrm{Pt} 4 \mathrm{f}$ region of $\mathrm{Pt}-\mathrm{Ni}_{2} \mathrm{P} /$ graphene and $\mathrm{Pt} / \mathrm{gra}-$ phene catalysts.

shown in Fig. 5a. The electrochemical surface area (ESA) is estimated from the integrated charge in the hydrogen/ adsorption region ( 0.03 to $0.4 \mathrm{~V}$ vs. RHE) of the CV curves. $^{35}$ The ESA of $\mathrm{Pt}-\mathrm{Ni}_{2} \mathrm{P} /$ graphene is calculated as $86.87 \mathrm{~m}^{2} \mathrm{~g}^{-1}$, $23 \%$ higher than that of $\mathrm{Pt} /$ graphene $\left(70.32 \mathrm{~m}^{2} \mathrm{~g}^{-1}\right)$, and these values are larger than the previously reported results, ${ }^{25}$ indicating that graphene may be able to provide better support for Pt nanoparticles than carbon-black. Moreover, the peak potential of the $\mathrm{Pt}-\mathrm{Ni}_{2} \mathrm{P} /$ graphene catalyst shifts towards
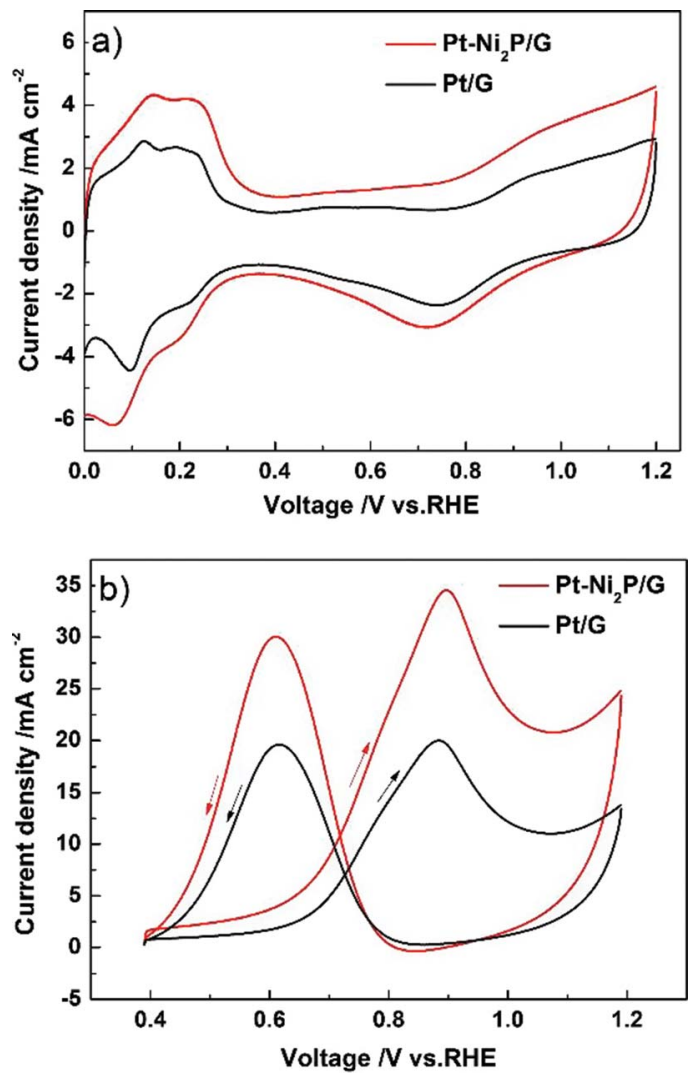

Fig. 5 Cyclic voltammetric curves with a scan rate of $50 \mathrm{mV} \mathrm{s}^{-1}$ for $\mathrm{Pt}-\mathrm{Ni}_{2} \mathrm{P} /$ graphene and $\mathrm{Pt} /$ graphene catalysts in $\mathrm{N}_{2}$ saturated $0.5 \mathrm{M}$ $\mathrm{H}_{2} \mathrm{SO}_{4}$ (a) and $1 \mathrm{M} \mathrm{CH}_{3} \mathrm{OH}+0.5 \mathrm{M} \mathrm{H}_{2} \mathrm{SO}_{4}$ (b) solutions. 
a negative direction when compared to that of the Pt/graphene catalyst, indicating the weakened adsorption strength of hydrogen on the Pt surface. ${ }^{36}$ This might be attributed to the hydrogen spillover effect of $\mathrm{Ni}_{2} \mathrm{P}$, which is considered to be beneficial for increasing the electrochemical surface area and eventually enhancing the utilization of Pt catalyst. Furthermore, additional experiments showed that compared with Pt$\mathrm{Ni}_{2} \mathrm{P}$ /graphene, the $\mathrm{Ni}_{2} \mathrm{P}$ has almost no catalytic activity (Fig. $\mathrm{S} 1 \dagger$ ). The results further illustrated that introducing $\mathrm{Ni}_{2} \mathrm{P}$ as cocatalyst can enhance the catalytic activity of the $\mathrm{Pt}-\mathrm{Ni}_{2} \mathrm{P}$ / graphene due to changing the electronic structure and density of state of Pt atoms and thus weaken the binding energy of strongly adsorbed.

The CV tests in $\mathrm{N}_{2}$ saturated $0.5 \mathrm{M} \mathrm{CH} \mathrm{CH}_{3} \mathrm{OH}+0.5 \mathrm{M} \mathrm{H}_{2} \mathrm{SO}_{4}$ solution were also conducted to examine the catalytic ability toward methanol oxidation, and the results are shown in Fig. $5 \mathrm{~b}$. It can be seen that the $\mathrm{Pt}-\mathrm{Ni}_{2} \mathrm{P} /$ graphene catalyst exhibits a higher peak current density than Pt/graphene does. The ratio between peak current densities in the forward $\left(i_{\mathrm{f}}\right)$ and backward $\left(i_{\mathrm{b}}\right)$ scan for $\mathrm{Pt}-\mathrm{Ni}_{2} \mathrm{P} /$ graphene and $\mathrm{Pt} /$ graphene is valued as 1.15 and 1.02 respectively, which reflects that $\mathrm{Pt}-\mathrm{Ni}_{2} \mathrm{P} /$ graphene has better tolerance to carbonaceous species. ${ }^{37}$ This result was further confirmed by the CO stripping test, as shown in Fig. 6. Compared to the $\mathrm{Pt} /$ graphene catalyst, the onset potential for $\mathrm{CO}_{\text {ads }}$ oxidation on $\mathrm{Pt}-\mathrm{Ni}_{2} \mathrm{P} /$ graphene catalyst is shifted negatively. ESA was also calculated from the CO oxidation area with an assumption that the charge of CO monolayer adsorption is $484 \mu \mathrm{C} \mathrm{cm}{ }^{-2}$, and the values for the $\mathrm{Pt}-\mathrm{Ni}_{2} \mathrm{P} /$ graphene and Pt/graphene catalysts are $80.7 \mathrm{~m}^{2} \mathrm{~g}^{-1}$ and 65.9 $\mathrm{m}^{2} \mathrm{~g}^{-1}$, respectively. This result proves that higher MOR activity and tolerance can be achieved with the corporation of $\mathrm{Ni}_{2} \mathrm{P}$ cocatalyst in $\mathrm{Pt}$ nanoparticles. The reason may be that the addition of $\mathrm{Ni}_{2} \mathrm{P}$ can weaken the accumulation of CO-like intermediates at $\mathrm{Pt}$ active sites. Moreover, as an initial hydrogen evolution catalyst, the presence of $\mathrm{Ni}_{2} \mathrm{P}$ self might also active water and accelerate hydrogen adsorption, producing $-\mathrm{OH}_{\mathrm{ads}}$ to oxidize $\mathrm{CO}$ and other poisoning intermediates adsorbed at adjacent Pt sites through the so-called bifunctional mechanism. $^{38}$

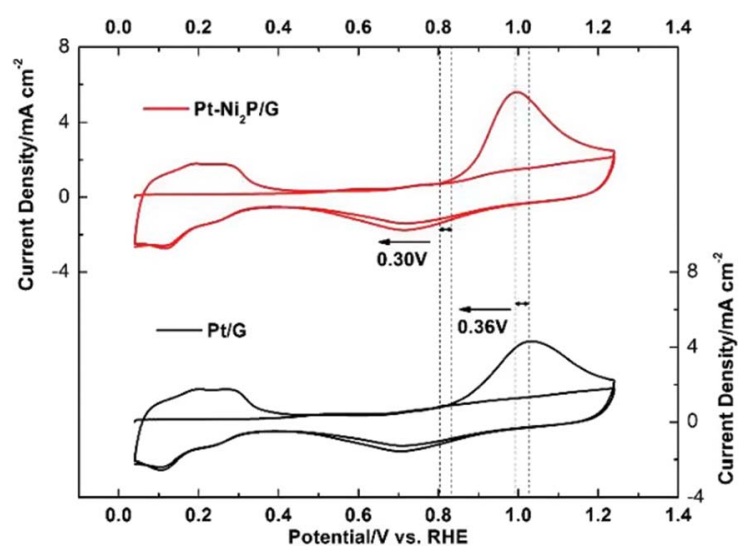

Fig. 6 Cyclic voltammetric curves with a scan rate of $50 \mathrm{mV} \mathrm{s}^{-1}$ for $\mathrm{Pt}-\mathrm{Ni}_{2} \mathrm{P} /$ graphene and $\mathrm{Pt} /$ graphene catalysts in $\mathrm{CO}_{\text {ads }}$ stripping voltammograms.
Finally, the typical current density-time responses at a fixed potential of $0.6 \mathrm{~V} v s$. RHE were measured in $\mathrm{N}_{2}$ saturated $0.5 \mathrm{M}$ $\mathrm{CH}_{3} \mathrm{OH}+0.5 \mathrm{M} \mathrm{H}_{2} \mathrm{SO}_{4}$ solution to test the stability toward methanol oxidation, and the results are shown in Fig. S2. $\dagger$ Because of the formation of intermediate species, such as $\mathrm{CO}_{\text {ads }}, \mathrm{CHO}_{\text {ads }}$ during the methanol oxidation reaction, ${ }^{39}$ the current densities decrease rapidly with the increment of time from the initial values of $c a .4 .80$ and $3.67 \mathrm{~mA} \mathrm{~cm}{ }^{-2}$ at $\mathrm{Pt}-\mathrm{Ni}_{2} \mathrm{P} /$ graphene and $\mathrm{Pt} /$ graphene, respectively. But, the decay rate at the $\mathrm{Pt}-\mathrm{Ni}_{2} \mathrm{P} /$ graphene catalyst is obviously smaller than that the Pt/graphene catalyst. Moreover, after $3000 \mathrm{~s}$, the stable current density at the $\mathrm{Pt}-\mathrm{Ni}_{2} \mathrm{P} /$ graphene catalyst (ca. $1.35 \mathrm{~mA}$ $\mathrm{cm}^{-2}$ ) is evidently higher than that at the Pt/graphene catalyst (ca. $0.77 \mathrm{~mA} \mathrm{~cm}^{-2}$ ). The result illustrates that the catalyst containing $\mathrm{Ni}_{2} \mathrm{P}$ displays favorable stability and higher catalytic activity for methanol oxidation, in agreement with the above results. Furthermore, the TEM images depicted in Fig. S3† showed that the original morphology of the $\mathrm{Pt}-\mathrm{Ni}_{2} \mathrm{P} /$ graphene catalyst was well preserved after typical current density-time responses measurement.

\section{Conclusions}

In summary, the $\mathrm{Pt}-\mathrm{Ni}_{2} \mathrm{P} /$ graphene catalyst was successfully synthesized via a microwave-assisted glycol process. The physical and chemical tests reveal that the addition of $\mathrm{Ni}_{2} \mathrm{P}$ greatly improves the electrocatalytic activity and stability with respect to methanol oxidation, which is probably attributed to the synergetic effects of an interface between the platinum and $\mathrm{Ni}_{2} \mathrm{P}$ and of a spillover due to diffusion of the reaction intermediates. $\mathrm{Ni}_{2} \mathrm{P}$ as a cocatalyst of $\mathrm{Pt}$ appears to be a promising application for less expensive direct methanol fuel cell.

\section{Conflicts of interest}

There are no conflicts to declare.

\section{Acknowledgements}

This work was supported by the National Natural Science Funds of China (No. 61404037, 61376113).

\section{References}

1 A. A. Kulikovsky, Electrochem. Commun., 2012, 24, 65-68.

2 Y. Li, X. L. Zhang, L. Nie, Y. F. Zhang and X. W. Liu, J. Power Sources, 2014, 245, 520-528.

3 Z. Yuan, Y. Zhang, W. Fu, Z. Li and X. Liu, Energy, 2013, 51, 462-467.

4 J. M. Cao, J. Zhou, Y. F. Zhang and X. W. Liu, RSC Adv., 2017, 7, 25867-25871.

5 Y. W. Huang, Q. J. Yu, J. Z. Wang, J. N. Wang, C. L. Yu, J. T. Abdalla, Z. Zeng, S. J. Jiao, D. B. Wang and S. Y. Gao, ACS Sustainable Chem. Eng., 2018, 6, 438-446.

6 S. M. Ni, Q. J. Yu, Y. W. Huang, J. N. Wang, L. Li, C. l. Yu, F. Y. Guo, H. G. Wu, W. J. Lu and X. T. Zhang, RSC Adv., 2016, 6, 85951-85957. 
7 Y. Vlamidis, S. Fiorilli, M. Giorgetti, I. Gualandi, E. Scavettaa and D. Tonelli, RSC Adv., 2016, 6, 110976-110985.

8 Z. Z. Jiang, Z. B. Wang, Y. Y. Chu, D. M. Gu and G. P. Yin, Energy Environ. Sci., 2011, 4, 728-735.

9 H. S. Liu, C. J. Song, L. Zhang, J. J. Zhang, H. J. Wang and D. P. Wilkinson, J. Power Sources, 2006, 155, 95-110.

10 S. Alayoglu, A. U. Nilekar, M. Mavrikakis and B. Eichhorn, Nat. Mater., 2008, 7, 333-338.

11 Z. L. Liu, X. Y. Ling, X. D. Su and J. Y. Lee, J. Phys. Chem. B, 2004, 108, 8234-8240.

12 W. J. Zhou, S. Q. Song, W. Z. Li, Z. H. Zhou, G. Q. Sun, Q. Xin, S. Douvartzides and P. Tsiakaras, J. Power Sources, 2004, 140, 50-58.

13 X. W. Zhou, R. H. Zhang, Z. Y. Zhou and S. G. Sun, J. Power Sources, 2011, 196, 5844-5848.

14 J. M. Cao, J. Zhou, Y. F. Zhang, Y. X. Wang and X. W. Liu, ACS Appl. Mater. Interfaces, 2018, 10, 1752-1760.

15 Y. Zhang, Y. W. Liu, M. Ma, X. Ren, Z. A. Liu, G. Du, A. M. Asiri and X. P. Sun, Chem. Commun., 2017, 53, 11048-11051.

16 C. Tang, L. S. Xie, K. Y. Wang, G. Du, A. M. Asiri, Y. L. Luo and X. P. Sun, J. Mater. Chem. A, 2016, 4, 12407-12410.

17 C. Tang, R. Zhang, W. B. Lu, Z. Wang, D. N. Liu, S. Hao, G. Du, A. M. Asiri and X. P. Sun, Angew. Chem., Int. Ed., 2017, 56, 842-846.

18 X. L. Xiong, C. You, X. Q. Cao, L. F. Pang, R. M. Kong and X. P. Sun, Electrochim. Acta, 2017, 253, 517-521.

19 W. J. Shi, Q. Wang, F. Qin, J. Yu, M. Jia, H. Gao, Y. Zhang, Y. Zhao and G. Li, Electrochim. Acta, 2017, 232, 332-338.

20 J. Wang, Q. Zhao, H. Hou, Y. Wu, W. Yu, X. Ji and L. Shao, RSC Adv., 2017, 7, 14152-14158.

21 S. Li, W. Guo, B. Yuan, D. Zhang, Z. Feng and J. Du, Sens. Actuators, B, 2017, 240, 398-407.

22 P. Wang, Y. Zhou, M. Hu and J. Chen, Appl. Surf. Sci., 2017, 392, 562-571.

23 J. F. Chang, L. G. Feng, C. P. Liu, W. Xing and X. L. Hu, Angew. Chem., Int. Ed., 2014, 53, 122-126.
24 G. Li, L. Feng, J. Chang, B. Wickman, H. Gronbeck, C. Liu and W. Xing, ChemSusChem, 2014, 7, 3374-3381.

25 J. Chang, L. Feng, C. Liu, W. Xing and X. Hu, Energy Environ. Sci., 2014, 7, 1628-1632.

26 J. M. Cao, J. Zhou, Y. F. Zhang and X. W. Liu, Sci. Rep., 2017, 18, 8825.

27 J. Zhou, J. M. Cao, Y. Z. Zou, Y. F. Zhang and X. W. Liu, Microelectron. Eng., 2017, 176, 89-93.

28 J. M. Cao, X. L. Zhang, Y. F. Zhang, J. Zhou, Y. N. Chen and X. W. Liu, PLoS One, 2016, 11, e0161374.

29 J. M. Cao, J. Zhou, Y. F. Zhang, Y. Z. Zou and X. W. Liu, PLoS One, 2017, 12, e0177258.

30 C. H. An, Y. J. Wang, Y. P. Wang, G. Liu, L. Li, F. Y. Qiu, Y. A. Xu, L. F. Jiao and H. T. Yuan, $R S C A d v$., 2013, 3, 4628-4633.

31 H. Huang, H. Chen, D. Sun and X. Wang, J. Power Sources, 2012, 204, 46-52.

32 G. M. Zhou, D. W. Wang, F. Li, L. L. Zhang, N. Li, Z. S. Wu, L. Wen, G. Q. Lu and H. M. Cheng, Chem. Mater., 2010, 22, 5306-5313.

33 Y. Huang, X. L. Huang, J. S. Lian, D. Xu, L. M. Wang and X. B. Zhang, J. Mater. Chem., 2012, 22, 2844-2847.

34 Y. Lu, X. L. Wang, Y. J. Mai, J. Y. Xiang, H. Zhang, L. Li, C. D. Gu, J. P. Tu and S. X. Mao, J. Phys. Chem. C, 2012, 116, 22217-22225.

35 Q. F. Li, R. H. He, J. A. Gao, J. O. Jensen and N. J. Bjerrum, J. Electrochem. Soc., 2003, 150, A1599-A1605.

36 I. Esparbe, E. Brillas, F. Centellas, J. A. Garrido, R. M. Rodriguez, C. Arias and P. Cabot, J. Power Sources, 2009, 190, 201-209.

37 Z. H. Zhang, Y. J. Huang, J. J. Ge, C. P. Liu and W. Xing, Electrochem. Commun., 2008, 10, 1113-1116.

38 Y. Chang, G. Han, M. Li and F. Gao, Carbon, 2011, 49, 51585165.

39 Y. Y. Shao, S. Zhang, C. M. Wang, Z. M. Nie, J. Liu, Y. Wang and Y. H. Lin, J. Power Sources, 2010, 195, 4600-4605. 